\title{
La Junta Local de Deslindes y Amojonamientos de Melilla (1866-1900)
}

\author{
Santiago Domínguez Llosá \\ $M^{\mathrm{a}}$ de los Angeles Rivas Ahuir \\ Asociación de Estudios Melillenses
}

El objeto de la presente comunicación es el estudio de la actuación de la Junta Local de Deslindes y Amojonamientos de Melilla, organismo creado en la segunda mitad del siglo pasado, y cuya principal misión era aclarar la caótica situación en la que se encontraban tanto las propiedades públicas como las particulares.

\section{CONBTITUCION}

La Junta Local de deslindes y Amojonamientos (a partir de ahora J.L.D.A.) fue creada en virtud de la Real Orden dada el 16 de octubre de 1865; la junta en sí, se formó el día 1 de julio de 1866, empezando sus trabajos el día 9 de agosto de ese mismo año.

\section{COMPOSICION}

La J.L.D.A. estaba compuesta por:

- Presidente: el señor Gobernador político-militar de la Plaza.

- Asesor: un abogado de los Tribunales de la Nación y de Pobres, proveniente de Ceuta.

- Vocales:

- Por el Ramo de Guerra: el Comisario de Guerra y Ministro de hacienda Militar.

- Por la Comandancia de Ingenieros: el Capitán Comandante del Arma en Melilla.

- Secretario: el Escribano público. 


\section{FINES DE I.A J.I.D.A.}

Llevar a cabo "un minucioso deslinde de las propiedades pertenecientes al Ramo de Guerra y de particulares en la Ciudad de Melilla".

\section{ACTUACION}

Como ya se ha indicado, la J.L.D.A. se reunió por primera vez el día 9 de agosto de 1866 en el pabellón-residencia del Gobernador de la Plaza. En esta primera reunión se dio lectura al escrito de constitución de la Junta, y a una comunicación, firmada por el Gobernador O'Ryan y Vázquez, de fecha 19 de diciembre de 1863, en la que se refiere al pésimo estado en el que se encontraban las edificaciones, tanto públicas como privadas, de la ciudad.

Este documento (anexo a esta comunicación), es excepcional para conocer el estado en el que se encontraba la ciudad, además de conocer un censo por profesiones de los habitantes civiles de Melilla.

En cada una de las reuniones de la Junta se revisaban los títulos de propiedad aportados por los propietarios (para lo cual dispusieron de un plazo de 20 días), que a continuación pasaban a dictamen del Asesor, quien los admitía o rechazaba.

La segunda fase consistía en el deslinde en sí de las fincas, empezando por los huertos de Santa Bárbara, y siguiendo por las edificaciones del $l^{\circ}$ y $2^{\circ}$ recintos. Para ello eran convocados los propietarios de la casa objeto del deslinde (o en su caso del huerto) y los de las casas (o huertos) contiguos.

$\mathrm{Si}$ al realizar la medición. y el consiguiente deslinde, todos los propietarios se monstraban conformes, el Gobernador, como Presidente de la Junta, cogía de la mano al propietario confirmado y lo paseaba por su propiedad. Sin embargo. si no existía dicho acuerdo, los interesados tenían diez días para hacer sus alegaciones, las cuales, estudiadas por el Asesor, eran o no admitidas, y en consecuencia se variaban los lindes o permanecían como estaban. También procuraba la Junta que los propietarios se pusieran de acuerdo amigablemente, y si no se conseguía, se acababa en un juicio ordinario para dilucidar el auténtico propietario de la finca en cuestión.

En cuanto a las propiedades del ramo de Guerra, es decir, del Estado, algunos de los antecedentes presentados por el Comisario de Guerra se remontaban a la época de la conquista, como por ejemplo en el caso de la Casa de Gobierno, usada con ese fin "desde tiempo inmemorial". Asi- 
mismo la actuación de la Junta en caso de contencioso con estas propiedades era contundente, al menos tres propietarios fueron desposeídos de partes de sus propiedades edificadas sobre predios pertenecientes al Estado.

\section{EL FINAL DE LA J.I.D.A.}

A lo largo de su actuación, la J.L.D.A. se reunió un total de 92 veces. Al principio de su funcionamiento, la actividad era constante, pero con el paso del tiempo se fue ralentizando hasta cesar del todo. Así, de las 5 o 6 reuniones mensuales de octubre de 1866 o mayo de 1867, se pasó a la única de septiembre de 1868, siendo la siguiente en el mes de febrero de 1870.

La causa principal de este cese hay que buscarla en la misma movilidad de los miembros de la Junta (al menos 4 Gobernadores diferentes la presidieron) que hacía que sus miembros se desconectasen del trabajo y nadie se ocupara de instruir a los suplentes en el trabajo ya realizado.

En 1889, el Capitán General de Granada, Brigadier Lasso, ordena que se investiguen las causas de la interrupción de los trabajos de la Junta, ordenando asimismo que se vuelva a constituir y continúe su obra clarificadora en el mismo punto donde se dejó.

Pero en ese documento se pierde la pista de la Junta, aunque algunos de los expedientes formados por ella se cierran en 1899. 
No se citan los nombres de los componentes de la J.L.D.A. por haher sido varios los que ocuparon los cargos, sin embargo los cinco primeros fueron:

- Presidertte: Gobernador don Bartolomé Benavides Campuzano.

- Asesor: don Federico Morales Albó.

- Vocales:

- Comisario de Guerra: don Pedro María García.

- Comandancia de Ingenieros: Capitán don Francisco César Roldán.

- Secretario: don Manuel Sánchez y Valenzuela.
Actas y Expedientes de la Jurita Local de Deslindes y Amojonamientos de Melilla, conservados en el Archivo Histórico Municipal.

DOMINGLEZ LLOSA, Santiago y RIVAS AHIIR, $M^{\text {a }}$ de los Angeles: "Apuntes sobre la propiedad rústica y urbana en Melilla en el siglo XIX ${ }^{n}$, Trápana: Revista de la Asociación de Estudios Melillenses, año 1, $\mathrm{r}^{\circ}$ 1, Melilla, enero 1987, págs. 29-34 y anexo. 